\title{
Pola Kemajuan Seleksi pada Cabai Rawit Spesies Capsicum annuum L.
}

\section{Selection Response Pattern of Chili Pepper (Capsicum annuum L.) Species}

\author{
Rosminah $^{1}$, Awang Maharijaya ${ }^{2}$, dan Muhamad Syukur ${ }^{2 *}$ \\ 'Program Studi Pemuliaan dan Bioteknologi Tanaman, Sekolah Pascasarjana, Institut Pertanian Bogor \\ ${ }^{2}$ Departemen Agronomi dan Hortikultura, Fakultas Pertanian, Institut Pertanian Bogor \\ (Bogor Agricultural University), Jl. Meranti, Kampus IPB Darmaga, Bogor 16680, Indonesia
}

Diterima 3 Juli 2018/Disetujui 15 Januari 2019

\begin{abstract}
Improvement of chilli's quantitative traits requires several stages of breeding program, one of these is selection stage. The objective of this study was to obtain the information concerning the means and ranges of some quantitative characters, inbreeding depression, heritability estimates, and response to selection from six generations derived from crossing two parents of chili peppers. Materials used were IPB C160 (female), IPB C291 (male) as parents, F2, F3, F4, F5, and F6 derived from crossing of these parents with a total number of 630 plants. Results from this study showed that the mean values between the generations F2 to F6 showed an increase in the observed character except of harvesting time. The highest value of inbreeding depression for harvest time, weight per fruit, and fruit length was found in F5 generation. The highest value of inbreeding depression for fruit weight per plant, number of fruit per plant, and fruit weight was found in F6 generation, and for fruit diameter was found in F4 generation. The narrow-sense heritability estimates were classified into low to moderate criteria. In general, declined responses to selection for quantitative characters in the six generations of chili were observed.
\end{abstract}

Keywords: advance selection, heritability, inbreeding depression, means value

\section{ABSTRAK}

Perbaikan cabai pada karakter kuantitatif memerlukan beberapa tahapan pemuliaan salah satunya melakukan seleksi. Tujuan penelitian adalah mendapatkan informasi mengenai nilai tengah dan selang beberapa karakter kuantitatif, tekanan silang dalam (inbreeding depression), nilai heritabilitas, dan kemajuan seleksi dari enam generasi hasil persilangan dua tetua cabai rawit. Bahan genetik yang digunakan terdiri dari dua tetua cabai yaitu genotipe IPB C160 (tetua betina), IPB C291 (tetua jantan) beserta hasil persilangan keduanya pada generasi F2, F3, F4, F5, dan F6 dengan total individu sebanyak 630 tanaman. Hasil penelitian menunjukkan bahwa berdasarkan nilai tengah antara generasi $F 2$ sampai F6 adanya peningkatan pada karakter yang diamati kecuali pada umur panen. Nilai inbreeding depression tertinggi untuk umur panen, bobot per buah, panjang buah terdapat pada generasi F5. Nilai inbreeding depression tertinggi untuk bobot buah per tanaman dan jumlah buah per tanaman terdapat pada generasi F6, dan diameter buah pada generasi F4. Nilai duga heritabilitas arti sempit dari karakter kuantitatif yang diamati termasuk dalam kisaran kriteria sedang dan rendah. Secara umum kemajuan seleksi untuk karakter kuantitatif pada enam generasi cabai yang diteliti menunjukkan penurunan.

Kata kunci: heritabilitas, inbreeding depression, kemajuan seleksi, nilai tengah

\section{PENDAHULUAN}

Cabai merupakan salah satu komoditas sayuran penting dan bernilai ekonomi tinggi di Indonesia. Cabai di Indonesia dikenal ada beberapa jenis, yaitu cabai besar, cabai keriting, dan cabai rawit. Salah satu cabai rawit yang ada di Indonesia berasal dari spesies Capsicum annuum L. (Syukur et al., 2012). Produksi cabai rawit pada tahun 2016 sebesar 915.997 ton dengan luas lahan 149.491 hektar

\footnotetext{
* Penulis untuk korespondensi. e-mail: muhsyukur@yahoo.com
}

(Badan Pusat Statistik, 2017). Namun demikian, produksi cabai rawit domestik belum dapat memenuhi permintaan kebutuhan cabai olahan untuk pasar dalam negeri. Oleh karena itu perlu dilakukan upaya peningkatan produktivitas, salah satunya melalui upaya perbaikan pada karakter kuantitatif lewat seleksi dari suatu program pemuliaan tanaman (Syukur et al., 2012).

Diharapkan varietas unggul baru (VUB) cabai rawit yang dilepas nantinya memiliki daya hasil tinggi dengan kualitas buah yang baik. Oleh karena itu perlu diketahui nilai heritabilitas dari karakter unggul yang dituju sebagai pengukur potensi genetik. Heritabilitas merupakan gambaran 
seberapa jauh suatu karakter dipengaruhi oleh faktor genetik atau lingkungan (Syukur et al., 2012). Menurut Yakub et al. (2012) karakter kuantitatif seperti daya hasil lebih besar dipengaruhi oleh faktor lingkungan. Karakter kuantitatif biasanya dikendalikan banyak gen yang masing-masing gen memiliki pengaruh kecil.

Kemajuan seleksi menggambarkan sejauh mana keefektifan proses seleksi. Seleksi akan efektif bila nilai kemajuan seleksi tinggi ditunjang oleh nilai keragaman genetik dan heritabilitas tinggi (Herawati et al., 2009). Menurut Adarsh dan Kumari (2015) nilai heritabilitas tinggi yang dikombinasikan dengan kemajuan genetik tinggi dapat dianggap sebagai indikasi aksi gen aditif. Menurut Arif et al. (2011) informasi-informasi tersebut dapat membantu pemulia dalam efektifitas perakitan varietas unggul baru (VUB). Tujuan dari penelitian ini adalah untuk mendapatkan informasi mengenai keragaan beberapa karakter kuantitatif, inbreeding depression, nilai heritabilitas, dan kemajuan seleksi dari enam generasi hasil persilangan cabai rawit IPB C160 x IPB C291.

\section{BAHAN DAN METODE}

PenelitianinidilakukandiKebunPercobaanLeuwikopo IPB dan dilanjutkan di Laboratorium Pendidikan Pemuliaan Tanaman, Departemen Agronomi dan Hortikultura, IPB pada bulan Maret hingga September 2017. Materi genetik yang digunakan yaitu genotipe IPB C160 (40 tanaman) sebagai tetua betina, IPB C291 (40 tanaman) sebagai tetua jantan beserta dengan generasi hasil persilangan keduanya yaitu F2 (200 tanaman), F3 (100 tanaman), F4 (100 tanaman), F5 (50 tanaman), dan F6 (100 tanaman) sehingga total jumlah individu seluruhnya adalah 630 tanaman. Intensitas seleksi yang digunakan untuk mendapatkan generasi tersebut sebesar $10 \%$. Semua genotipe ditanam bersamaan waktunya. Pengamatan karakter kuantitatif berdasarkan deskriptor IPGRI (1995) yaitu umur panen (hari setelah tanam/HST), jumlah buah per tanaman (buah), bobot buah per tanaman (g per tanaman), bobot per buah $(\mathrm{g})$, panjang buah $(\mathrm{cm})$, dan diameter buah ( $\mathrm{mm})$.

Analisis data kuantitatif yang digunakan meliputi pendugaan nilai tengah dan selang untuk mendapatkan gambaran hasil seleksi yang telah dilakukan. Tekanan silang dalam (Inbreeding Depression) dihitung menggunakan rumus

$\mathrm{ID}=\frac{\overline{\mathrm{X}}_{F n}-\overline{\mathrm{X}}_{\mathrm{F} 2}}{\overline{\mathrm{X}}_{F 2}} \times 100 \%$

(ID $=$ inbreeding depression, $\overline{\mathrm{X}}_{\mathrm{Fn}}=$ rata-rata generasi $\mathrm{F}_{\mathrm{n}}$, dan $\bar{X}_{\mathrm{F} 2}=$ rata-rata generasi ${ }_{\mathrm{F} 2}$ ). Kemajuan seleksi dihitung menggunakan rumus: $\mathrm{G}=\overline{\mathrm{F}}_{3}-\overline{\mathrm{F}}_{2}, \mathrm{G}=\overline{\mathrm{F}}_{4}-\overline{\mathrm{F}}_{3}, \mathrm{G}=\overline{\mathrm{F}}_{5}-\overline{\mathrm{F}}_{4}$ dan $\mathrm{G}=\overline{\mathrm{F}}_{6}-\overline{\mathrm{F}}_{5}\left(\overline{\mathrm{F}}_{2}=\right.$ rata-rata generasi $\mathrm{F}_{2}, \overline{\mathrm{F}}_{3}=$ rata-rata generasi $\mathrm{F}_{3}, \overline{\mathrm{F}}_{4}=$ rata-rata generasi $\mathrm{F}_{4}, \overline{\mathrm{F}}_{5}=$ rata-rata generasi $\mathrm{F}_{5}$, dan $\overline{\mathrm{F}}_{6}=$ rata-rata generasi $\mathrm{F}_{6}$ ) (Syukur et al., 2012). Perhitungan $\mathrm{h}^{2}$ mengacu pada Mahmud dan Kramer (1951) menggunakan regresi parent-offspring $\mathrm{h}^{2}{ }_{\mathrm{ns}}=\mathrm{b} \times 100 \%$, dengan

$\mathrm{b}=\frac{\operatorname{Cov}(\mathrm{Fn}-1 \& \mathrm{Fn})}{\sigma^{2} \mathrm{Fn}-1}$ $\left(\mathrm{h}^{2}{ }_{\mathrm{ns}}=\right.$ heritabilitas arti sempit dan $\sigma^{2}{ }_{\mathrm{Fn}}=$ ragam populasi Fn). Nilai duga heritabilitas digolongkan menjadi tiga kriteria yaitu tinggi $(50 \% \leq$ heritabilitas $<100 \%)$, sedang $(20 \% \leq$ heritabilitas $<50 \%)$, dan rendah $(0 \% \leq$ heritabilitas $<20 \%$ ) (Stanfield, 1983).

\section{HASIL DAN PEMBAHASAN}

Nilai Tengah dan Selang Beberapa Karakter Kuantitatif dari Enam Generasi Cabai Rawit Hasil Persilangan IPB C160 x IPB C291

Nilai tengah dan selang nilai karakter kuantitatif dari enam generasi cabai rawit hasil persilangan IPB C160 x IPB C291 dapat dilihat pada Tabel 1. Nilai selang semua karakter kuantitatif yang diamati pada generasi F2 menunjukkan lebih luas dibandingkan dengan generasi lainnya. Artinya keragaman F2 lebih tinggi dibandingkan dengan generasi F3, F4, F5, dan F6. Yunandra et al. (2017) menyatakan bahwa populasi F2 memiliki ragam yang lebih luas dibandingkan generasi berikutnya karena kegiatan seleksi. Menurut Zecevic et al. (2011) generasi F2 merupakan generasi yang memiliki rekombinasi gen paling maksimum.

Data selang F3 lebih rendah dibandingkan nilai selang pada generasi F4 pada karakter umur panen, bobot per buah, panjang buah, dan diameter buah serta generasi F6 pada karakter panjang buah. Data selang generasi F4 lebih rendah dibanding dengan generasi F5 pada karakter bobot buah per tanaman, sedangkan pada generasi F6 memiliki nilai selang lebih tinggi dibandingkan generasi F5 kecuali pada karakter umur panen. Hal ini menunjukkan bahwa setelah dilakukan kegiatan seleksi pedigree pada generasi cabai yang diamati, terdapat beberapa generasi yang memiliki keragaman lebih tinggi dibandingkan dengan generasi sebelumnya. Ini diduga karena terjadi penyerbukan silang alami pada generasi F6 sehingga terjadi segregasi maksimum seperti pada generasi awal. Ritonga (2013) melaporkan bahwa pada populasi cabai generasi F8 dan F9 mengalami segregasi maksimum sehingga memiliki nilai ragam genetik yang tinggi.

Generasi F2 memiliki rata-rata nilai tengah umur panen pertama tercepat (69.93 HST), diikuti oleh generasi F3, F4, F6, dan F5 dengan nilai berturut-turut yaitu 78.02, 79.00, 79.79, dan 79.81 HST (Tabel 1). Qosim et al. (2013) menyatakan bahwa cabai berumur genjah jika umur panen kurang dari 115.00 HST untuk cabai merah. Jika mengacu pada Qosim et al. (2013) maka genotipe cabai F2 sampai F6 hasil silangan IPB C160 x C291 termasuk dalam kisaran umur genjah.

Panjang buah mengalami peningkatan dari generasi F2 sampai generasi F5 dan mengalami penurunan pada generasi F6. Pola yang sama juga terjadi pada karakter bobot per buah. Nilai tengah diameter buah tertinggi pada generasi F4 dan mengalami penurunan pada generasi F5 dan F6. Perbedaan karakter panjang buah dan diameter buah berpengaruh pada karakter bobot buah. Walaupun pada karakter bobot per buah, panjang buah, dan diameter buah mengalami penurunan pada generasi F6, namun hal tersebut tidak terjadi pada bobot buah per tanaman. Hal ini 
Rosminah et al. / J. Agron. Indonesia 47(1):47-52

Tabel 1. Nilai tengah dan selang pada beberapa generasi cabai rawit $C$. annuum L.

\begin{tabular}{llcccccc}
\hline \multirow{2}{*}{ Karakter } & Parameter & \multicolumn{5}{c}{ Generasi } & Selisih $\bar{x}$ \\
\cline { 3 - 7 } & & F2 & F3 & F4 & F5 & F6 & F2 dan F6 \\
\hline \multirow{2}{*}{ UP } & $\bar{x}$ & 69.93 & 78.02 & 79.00 & 79.81 & 79.79 & 9.86 \\
& Selang & $53-88$ & $65-88$ & $63-89$ & $66-87$ & $72-88$ & \\
\multirow{2}{*}{ BBP } & $\bar{x}$ & 267.20 & 279.94 & 188.03 & 302.04 & 364.08 & 96.90 \\
& Selang & $42.89-802.40$ & $65.59-671.41$ & $33.82-432.44$ & $86.65-507.46$ & $134.45-740.12$ & \\
JBP & $\bar{x}$ & 312.6 & 307.22 & 164.96 & 253.04 & 322.81 & 10.20 \\
& Selang & $72-836$ & $163-803$ & $41-497$ & $78-408$ & $161-723$ & \\
BP & $\bar{x}$ & 1.61 & 1.88 & 2.14 & 2.39 & 2.36 & 0.75 \\
& Selang & $0.61-3.04$ & $1.29-3.61$ & $1.03-3.39$ & $1.53-3.26$ & $1.41-3.73$ & \\
PB & $\bar{x}$ & 4.70 & 5.39 & 5.87 & 6.25 & 5.70 & 0.99 \\
& Selang & $3.40-9.46$ & $4.10-7.14$ & $4.04-7.50$ & $5.00-7.54$ & $4.12-7.54$ & \\
DB & $\bar{x}$ & 9.32 & 9.76 & 10.30 & 10.13 & 10.06 & 0.74 \\
& Selang & $6.90-12.46$ & $8.53-12.43$ & $8.15-12.63$ & $8.50-12.21$ & $8.22-12.02$ & \\
\hline
\end{tabular}

Keterangan: $\mathrm{UP}=$ umur panen $(\mathrm{HST})$; $\mathrm{BBP}=$ bobot buah pertanaman $(\mathrm{g})$; JBP $=$ jumlah buah per tanaman $($ buah); $\mathrm{BP}=$ bobot per buah (g); $\mathrm{PB}=$ panjang buah $(\mathrm{cm}) ; \mathrm{DB}=$ diameter buah $(\mathrm{mm})$

terbukti dari nilai tengah bobot buah per tanaman tertinggi pada pada generasi F6, sedangkan terendah pada generasi F4 kemudian diikuti oleh generasi F2. Penurunan nilai tengah yang terjadi pada beberapa karakter seperti bobot per buah, jumlah buah per tanaman, bobot per buah, panjang buah, dan diameter buah diduga karena adanya hama dan penyakit pada cabai. Adapun terjadi peningkatan nilai tengah karena adanya kegiatan seleksi yang dilakukan pada beberapa generasi cabai.

Nilai tengah dari karakter bobot buah per tanaman tidak konsisten dari generasi ke generasi. Pada generasi F2F3 meningkat, tapi menurun di F4, lalu meningkat kembali pada generasi F5-F6. Karakter jumlah buah per tanaman mengalami penurunan terbesar pada generasi F4 dan meningkat kembali hingga generasi F6. Bobot dan jumlah buah per tanaman terbanyak pada generasi F6 dan terendah pada generasi F4. Penurunan ini diduga adanya hama dan penyakit yang menyerang cabai terutama pada generasi F4. Namun jika dilihat dari selisih nilai tengah antara generasi F2 dan F6 menunjukkan adanya peningkatan pada karakter yang diamati kecuali pada umur panen. Umur panen yang diinginkan adalah berumur genjah. Sujitno dan Dianawati (2015) melaporkan bahwa produksi buah dipengaruhi oleh tinggi tanaman, diameter buah, dan panjang buah. Sharma et al. (2010) menyatakan bahwa panjang buah dan jumlah buah per tanaman berkorelasi positif terhadap bobot buah per tanaman. Menurut Agastya et al. (2017) penurunan produksi sebagian besar dipengaruhi oleh hama, penyakit tanaman, dan gulma. Selain itu, Dalimunthe et al. (2015) dan Dewi et al. (2016) menyatakan bahwa kendala yang menyebabkan menurunnya produksi cabai rawit yaitu hama dan penyakit.

\section{Tekanan Silang Dalam (Inbreeding Depression)}

Secara umum nilai inbreeding depression dari generasi ke generasi berbeda-beda untuk setiap karakter (Tabel 2). Karakter dengan nilai inbreeding depression bernilai positif menunjukkan tidak mengalami inbreeding depression dan jika nilai inbreeding depression bernilai negatif maka mengalami inbreeding depression. Nilai inbreeding depression tertinggi untuk umur panen terjadi pada generasi F5 (14.13\%), dan terendah pada generasi F3 (11.57\%). Karakter lain seperti bobot dan jumlah buah per tanaman memiliki nilai inbreeding depression tertinggi pada generasi F6 (36.26\% dan 3.26\%), bobot per buah dan panjang buah tertinggi pada generasi F5 (48.58\% dan $32.95 \%)$, dan untuk diameter buah tertinggi pada generasi F4 (10.44\%). Karakter tersebut tidak mengalami inbreeding depression karena nilai yang diperoleh bernilai positif.

Bobot dan jumlah buah per tanaman memiliki nilai inbreeding depression terendah pada generasi F4, sedangkan karakter bobot per buah, panjang buah, dan diameter buah terendah pada generasi F3. Bobot dan jumlah buah per tanaman memiliki nilai inbreeding depression terendah dibandingkan dengan karakter lainnya. Hal ini menunjukkan bahwa ada penurunan pada karakter tersebut. Penurunan yang terjadi bukan dikarenakan inbreeding depression, akan tetapi penurunan pada karakter tersebut diduga akibat hama dan penyakit.

\section{Heritabilitas Arti Sempit}

Nilai heritabilitas suatu karakter penting untuk mengetahui apakah karakter tersebut dipengaruhi oleh 
Tabel 2. Nilai tekanan silang dalam (inbreeding depression) pada beberapa generasi cabai rawit C. annuum L.

\begin{tabular}{lcccc}
\hline \multirow{2}{*}{ Karakter } & \multicolumn{5}{c}{ Tekanan silang dalam (\%) } \\
\cline { 2 - 5 } & F3 & F4 & F5 & F6 \\
\hline UP & 11.57 & 12.97 & 14.13 & 14.11 \\
BBP & 4.77 & -29.63 & 13.04 & 36.26 \\
JBP & -1.72 & -47.23 & -19.05 & 3.26 \\
BP & 17.10 & 33.27 & 48.58 & 46.74 \\
PB & 14.61 & 24.83 & 32.95 & 21.11 \\
DB & 4.70 & 10.44 & 8.62 & 7.96 \\
\hline
\end{tabular}

Keterangan: Angka dengan nilai positif menunjukkan tidak mengalami inbreeding depression dan angka dengan nilai negatif menunjukkan mengalami inbreeding depression; $\mathrm{UP}=$ umur panen (HST); $\mathrm{BBP}=$ bobot buah per tanaman $(\mathrm{g})$; JBP $=$ jumlah buah per tanaman (buah); $\mathrm{BP}=$ bobot per buah (g); $\mathrm{PB}=$ panjang buah $(\mathrm{cm}) ; \mathrm{DB}=\operatorname{diameter}$ buah $(\mathrm{mm})$

faktor genetik atau lingkungan. Tabel 3 menunjukkan bahwa nilai heritabilitas dalam arti sempit pada beberapa karakter kuantitatif yang diamati dari enam generasi hasil persilangan cabai rawit IPB C160 x IPB C291 berada pada kriteria rendah hingga sedang, artinya karakter tersebut sedikit dipengaruhi oleh gen-gen aditif. Putri et al. (2009) menyatakan bahwa nilai heritabilitas yang tinggi menggambarkan penampilan lebih dipengaruhi oleh faktor genetik dibandingkan faktor lingkungan. Jadi nilai heritabilitas arti sempit tinggi berarti karakter tersebut lebih dipengaruhi dari kerja gen-gen aditif yang dapat diwariskan pada generasi berikutnya.

Hasil pengamatan menunjukkan bahwa beberapa karakter kuantitatif dari enam generasi cabai rawit hasil persilangan IPB C160 x IPB C291 memiliki nilai heritabilitas arti sempit dalam kriteria 'sedang', di antaranya: umur panen pada generasi F2; bobot buah per tanaman pada generasi F4; jumlah buah per tanaman pada generasi F2, F3, dan F4; serta bobot per buah dan panjang buah pada generasi F5. Nilai heritabilitas arti sempit kriteria sedang juga dilaporkan Arif et al. (2014) pada umur panen.

Adapun nilai heritabilitas arti sempit dengan kriteria 'rendah' terjadi pada karakter umur panen pada generasi F3, F4, dan F5; bobot buah per tanaman pada generasi F2, F3, dan F5; jumlah buah per tanaman pada generasi F5; bobot per buah dan panjang buah kecuali pada generasi F5; dan diameter buah untuk semua generasi yang diamati. Hasil yang sama diperoleh Arif et al. (2012) pada umur panen, Syukur dan Rosidah (2014) pada panjang buah dan diameter buah, dan Yunandra et al. (2017) pada jumlah buah per tanaman. Seleksi pada karakter yang nilai heritabilitasnya rendah akan berlangsung relatif kurang efektif, karena karakter tersebut sedikit dipengaruhi oleh gen-gen aditif sehingga sulit untuk diwariskan ke generasi berikutnya.

\section{Kemajuan Seleksi}

Kemajuan seleksi dapat merubah frekuensi gen ke arah yang dituju. Seleksi yang dilakukan dapat diarahkan untuk memperbesar gen yang diinginkan (Syukur et al., 2012). Tabel 4 menunjukkan bahwa kemajuan seleksi dari generasi F3 hingga F6 bernilai positif dan negatif. Namun secara umum nilai kemajuan seleksi tidak konsisten dari generasi ke generasi. Nilai kemajuan seleksi karakter umur panen pada generasi F3, F4, F5, dan F6 mengalami penurunan.

Karakter umur panen mengalami penurunan nilai kemajuan seleksi pada generasi F3, F4, F5, dan F6. Karakter panjang buah memiliki nilai kemajuan seleksi tertinggi pada generasi F3 (0.69), sedangkan terendah pada generasi

Tabel 3. Nilai heritabilitas arti sempit $\left(\mathrm{h}^{2} \mathrm{~ns}\right)$ pada beberapa generasi cabai rawit $C$. annuum $\mathrm{L}$.

\begin{tabular}{lrrrr}
\hline \multirow{2}{*}{ Karakter } & \multicolumn{5}{c}{ Heritabilitas arti sempit $\left(\mathrm{h}^{2} \mathrm{~ns}\right)(\%)$} & F5 \\
\cline { 2 - 5 } & $\mathrm{F} 2$ & $\mathrm{~F} 3$ & $\mathrm{~F} 4$ & 0.00 \\
UP & 23.60 & 0.00 & 0.00 & 1.60 \\
BBP & 1.10 & 2.70 & 27.00 & 0.00 \\
JBP & 25.70 & 33.00 & 21.40 & 24.80 \\
BP & 0.00 & 0.00 & 0.00 & 35.50 \\
PB & 0.00 & 0.00 & 11.90 & 0.00 \\
DB & 0.00 & 7.50 & 4.20 & \\
\hline
\end{tabular}

Keterangan: UP = umur panen $(\mathrm{HST})$; $\mathrm{BBP}=$ bobot buah per tanaman $(\mathrm{g})$; JBP $=$ jumlah buah per tanaman $(\mathrm{buah})$; $\mathrm{BP}=$ bobot per buah (g); $\mathrm{PB}=$ panjang buah $(\mathrm{cm}) ; \mathrm{DB}=$ diameter buah $(\mathrm{mm})$ 
F6 (-0.56). Nilai kemajuan seleksi pada diameter buah tertinggi pada generasi F4 (0.54), sedangkan terendah untuk diameter buah pada generasi F5 (-0.17).

Karakter bobot per buah memiliki nilai kemajuan seleksi tertinggi pada generasi F3 (0.27), sedangkan terendah adalah generasi F6 (-0.03). Bobot buah per tanaman tertinggi pada generasi F5 (114.01), sedangkan terendah pada generasi F4 (-91.91). Nilai kemajuan seleksi pada jumlah buah pertanaman tertinggi pada generasi F5 (88.07), sedangkan terendah pada generasi F4 (-142.26).
Berdasarkan karakter kuantitatif yang diamati, dapat diketahui bahwa nilai kemajuan seleksi tertinggi adalah bobot dan jumlah buah per tanaman. Hal ini diperkuat oleh hasil penelitian Sidiq et al. (2017) yang menginformasikan kemajuan seleksi tertinggi terjadi pada bobot dan jumlah buah per tanaman. Dengan demikian pada penelitian ini dapat diketahui bahwa peningkatan kemajuan karakter bobot dan jumlah buah per tanaman tiap generasi dapat dilakukan melalui kegiatan seleksi, sedangkan kegiatan seleksi untuk karakter lainnya menyebabkan terjadinya penurunan.

Tabel 4. Nilai kemajuan seleksi pada beberapa generasi cabai rawit $C$. annuum L.

\begin{tabular}{|c|c|c|c|c|}
\hline \multirow{2}{*}{ Karakter } & \multicolumn{4}{|c|}{ Kemajuan seleksi } \\
\hline & F3 & F4 & F5 & F6 \\
\hline UP & 8.09 & 0.98 & 0.81 & -0.02 \\
\hline BBP & 12.73 & -91.91 & 114.01 & 62.04 \\
\hline JBP & -5.38 & -142.26 & 88.07 & 69.77 \\
\hline $\mathrm{BP}$ & 0.27 & 0.26 & 0.25 & -0.03 \\
\hline PB & 0.69 & 0.48 & 0.38 & -0.56 \\
\hline DB & 0.44 & 0.54 & -0.17 & -0.06 \\
\hline
\end{tabular}

Keterangan: UP = umur panen (HST); BBP = bobot buah per tanaman $(\mathrm{g})$; JBP = jumlah buah per tanaman $($ buah); $\mathrm{BP}=$ bobot per buah $(\mathrm{g}) ; \mathrm{PB}=$ panjang buah $(\mathrm{cm}) ; \mathrm{DB}=$ diameter buah $(\mathrm{mm})$

\section{KESIMPULAN}

F6 $\begin{array}{cccc}\text { Nilai tengah antara generasi } \mathrm{F} 2 & \text { dan } \\ \text { menunjukkan } & \text { adanya }\end{array}$ karakter yang diamati kecuali pada umur panen. Nilai inbreeding depression untuk umur panen (14.13\%), bobot per buah (48.58\%), panjang buah $(32.95 \%)$ tertinggi pada generasi F5, bobot (36.26\%) dan jumlah buah per tanaman (3.26\%) pada generasi F6, dan diameter buah pada generasi F4 (10.44\%). Karakter yang diamati tidak mengalami inbreeding depression. Nilai heritabilitas arti sempit dari beberapa karakter kuantitatif yang diamati termasuk dalam kriteria 'sedang', yaitu umur panen pada generasi F2, bobot buah pertanaman pada generasi F4, jumlah buah per tanaman pada generasi F2, F3, dan F4, bobot per buah dan panjang buah pada generasi F5, sedangkan untuk generasi dan karakter lainnya termasuk dalam kriteria 'rendah'. Kemajuan seleksi pada enam generasi cabai yang diteliti secara umum menunjukkan penurunan.

\section{UCAPAN TERIMA KASIH}

Terima kasih disampaikan kepada Kementerian Riset, Teknologi dan Pendidikan Tinggi (RISTEKDIKTI) yang telah membiayai penelitian ini melalui Hibah Terapan Penelitian Unggulan Perguruan Tinggi (PUPT) IPB tahun 2017 a.n. Muhamad Syukur.

\section{DAFTAR PUSTAKA}

Adarsh, M.N., P. Kumari. 2015. Combining ability and gene action studies for important horticultural traits in chilli, Capsicum annuum L. Int. J. Farm. Sci. 5:251262.

Agastya, I.I.M., R.D.P. Julianto, A. Hamzah. 2017. Teknik pengendalian penyakit antraknose (patek) di sentra tanaman cabai (Capsicum annuum L.) menggunakan pendekatan PHT. J. Akses Pengabdian Indonesia $1: 28-31$.

Arif, A.B., L. Oktaviana, S. Sujiprihati, M. Syukur. 2014. Pendugaan parameter genetik karakter umur panen dan bobot per buah pada persilangan cabai besar dan cabai rawit (Capsicum annuum L.). Bul. Plasma Nutfah 20:11-18.

Arif, A.B., S. Sujiprihati, M. Syukur. 2011. Pewarisan sifat beberapa karakter kualitatif pada tiga kelompok cabai. Bul. Plasma Nutfah 17:73-74.

Arif, A.B., S. Sujiprihati, M. Syukur. 2012. Pendugaan parameter genetik pada beberapa karakter kuantitatif pada persilangan antara cabai besar dengan cabai keriting (Capsicum annuum L.). J. Agron. Indonesia 40:119-124. 
Badan Pusat Statistik. 2017. Luas lahan, produksi cabai rawit tahun 2016. http://bps.go.id/ [28 Desember 2017].

Dalimunthe, S.R., A.B. Arif, S. Sujiprihati, M. Syukur. 2015. Pendugaan parameter genetik pada persilangan dialel beberapa tetua cabai (Capsicum annuum L.). J. Informatika Pertanian 24:1-8.

Dewi, A.A., Ainurrasjid, D. Saptadi. 2016. Identifikasi ketahanan tujuh genotip cabai rawit (Capsicum frutescens L.) terhadap Phytophthora capsici (penyebab penyakit busuk batang). J. Produksi Tanaman 4:174-179.

Herawati, R., B.S. Purwoko, I.S. Dewi. 2009. Keragaman genetik dan karakter agronomi galur haploid ganda padi gogo dengan tipe baru hasil kultur antera. J. Agron. Indonesia 37:87-94.

IPGRI. 1995. Descriptors for Capsicum (Capsicum spp.). International Plant Genetic Resources Institute, Italy, IT.

Mahmud, I., H.H. Kramer. 1951. Segregation for yield, height, and maturity following a soybean cross. Agron. J. 43:605-609.

Putri, L.A.P., Sudarsono, H. Aswidinnoor, D. Asmono. 2009. Keragaan genetik dan pendugaan heritabilitas pada komponen hasil dan kandungan $\beta$-karoten porgeni kelapa sawit. J. Agron. Indonesia 37:145-151.

Qosim, W.A., M. Rachmadi, J.S. Hamdani, I. Nuri. 2013. Penampilan fenotipik, variabilitas dan heritabilitas 32 genotip cabai merah berdaya hasil tinggi. J. Agron. Indonesia 41:140-146.

Ritonga, A.W. 2013. Penyerbukan silang alami beberapa genotipe cabai (Capsicum annuum L.) dan penentuan metode pemuliaannya. Tesis. Sekolah Pascasarjana. Institut Pertanian Bogor. Bogor.
Sharma, V.K., C.S. Semwal, S.P. Uniyal. 2010. Genetic variability and character association analysis in bell pepper (Capsicum annuum L.). J. Hortic. For. 2:058065.

Sidiq, A.F.R., M. Syukur, S. Marwiyah. 2017. Pendugaan parameter genetik dan seleksi karakter kuantitatif cabai rawit (Capsicum annuum L.) populasi F3. Bul. Agrohorti 5:213-225.

Stanfield, W.D. 1983. Theory and Problems of Genetics 2nd Schain's Outline Series. Mc Grow thill Book Co, New Delhi, IN.

Sujitno, E., M. Dianawati. 2015. Produksi panen berbagai varietas unggul baru cabai rawit (Capsicum frutescens) di lahan kering Kabupaten Garut, Jawa Barat. Pros. Sem. Nas. Masy. Biodiv. Indon. 1:874877.

Syukur, M., S. Rosidah. 2014. Estimation of genetic parameter for quantitative characters of pepper (Capsicum annuum L.). J. Trop. Crop Sci. 1:4-8.

Syukur, M., S. Sujiprihati, R. Yunianti. 2012. Teknik Pemuliaan Tanaman. Penebar Swadaya, Depok, ID.

Yakub, S., A.M. Kartina, S. Isminingsih, M.L. Suroso. 2012. Pendugaan parameter genetik hasil dan komponen hasil galur-galur padi lokal asal Banten. J. Agro. 17:1-6.

Yunandra, M. Syukur, A. Maharijaya. 2017. Seleksi dan kemajuan seleksi karakter komponen hasil pada persilangan cabai keriting dan cabai besar. J. Agron. Indonesia 45:169-174.

Zecevic, B., R. Dordevic, A. Balkaya, J. Damnjanovic, M. Dordevic, A. Vujoševic. 2011. Influence of parental germplasm for fruit characters in F1, F2, and F3 generations of pepper (Capsicum annuum L.). Genetika 43:209-216. 